Article

\title{
City-Life No More? Young Adults' Disrupted Urban Experiences and Their Digital Mediation under Covid-19
}

\author{
Katja Kaufmann ${ }^{1,2, *}$, Christoph Straganz ${ }^{1}$ and Tabea Bork-Hüffer ${ }^{1}$ \\ ${ }^{1}$ Department of Geography, University of Innsbruck, 6020 Innsbruck, Austria; E-Mails: katja.kaufmann@uibk.ac.at (K.K.), \\ christoph.straganz@student.uibk.ac.at (C.S.), tabea.bork-hueffer@uibk.ac.at (T.B.-H.) \\ 2 Institute for Comparative Media and Communication Studies, 1010 Vienna, Austria \\ * Corresponding author
}

Submitted: 14 July 2020 | Accepted: 2 September 2020 | Published: 15 December 2020

\begin{abstract}
The Covid-19 pandemic temporarily, yet significantly, reshuffled the position, functions and (mediated) constructions of cities and urban places. The national lockdown, implemented by Austria on 16 March 2020, turned cities overnight from centres of hybrid cultural, economic, social, political life and power to places where urban life(styles) were put on hold. This article begins by presenting first key results of a longitudinal study with young adults studying in educational institutions in the state of Tyrol through the harshest country-wide lockdown measures and their gradual withdrawal. We analyse how participants coped with the disruption of their urban lives and lifestyles and the strategies they employed to compensate. We highlight three main insights. First, participants who had originally migrated to the city from their (often rural) hometowns largely returned to join their families. From there, no longer being an object of physical experience, the city became a digitally imagined, constructed and communicated place, reiterating public discourses that condemned the city as a place where lockdown measures were breached, and the virus spread unchecked. Second, where possible and adapted to the affordances of digital media, students shifted their previous lifestyles to digital space as well as created innovative ways of socialising digitally-thus producing alternative digital forms of urban lifestyles and digitally-mediated urban experiences. Third, during the lockdown period, the importance, use intensity as well as a variety of digital media peaked tremendously. This trend, however, was short-lived as yearned-for offline sociability largely returned to the city once measures were relaxed, leaving those in rural homes detached from their urban peers.
\end{abstract}

\section{Keywords}

Austria; digitally-mediated city; mobile youth culture; pandemic; urban experiences; urban ills; urban imaginaries; urban lifestyles; urban pathology; young people

\section{Issue}

This article is part of the issue "Digital Geographies and the City" edited by Wen Lin (Newcastle University, UK).

(C) 2020 by the authors; licensee Cogitatio (Lisbon, Portugal). This article is licensed under a Creative Commons Attribution 4.0 International License (CC BY).

\section{Introduction}

The Covid-19 pandemic struck unprepared global societies in 2020 and, within weeks, it "profoundly transformed the familial spaces of home, modes of living, and the geographies of everyday lives" (Rose-Redwood et al., 2020 , p. 99). In the (social) media discourses accompanying the pandemic, the city is framed in contrasting ways: Visuals either show the city as deserted space, bereft of all that makes it liveable or as urban public place filled with (often young) people ignoring social distancing regulations, signalling an indifference to social others in the city. Hence, in the public discourse, the pandemic shifted the position of the city from a place where life is happening to a place decried for its population numbers and density, for people breaching regulations that are intended to contain the virus and to, overall, a place that potentially reinforces virus transmission. During the Covid-19 pandemic, mediated discourses and imaginaries of cities emerged, which remind us, as urban scholars, of con- 
structions of the city as urban ill that had prominently been produced, particularly by sociologists, from the 19th century onward (see Hubbard, 2006).

This article presents results of the first two phases of an on-going longitudinal study that accompanied students enrolled in universities in the Austrian city of Innsbruck in the province of Tyrol, throughout the pandemic and during the state's and country's farreaching lockdown measures and their gradual withdrawal in spring 2020. Innsbruck, the provincial capital and one of the university towns of Austria, has a population of 133,206 (as of January 2020; Landeshauptstadt Innsbruck, 2020) and is located in the scenic Alps in the West of the country. Some 35,000 students are enrolled in the city's higher education institutions (Austrian Agency for International Cooperation in Education and Research, 2017). During the pandemic, Tyrol involuntarily rose to fame when some of its popular ski resorts, among them most prominently the resort of Ischgl, were identified as early hotspots of the Covid-19 spreading in spring 2020 across Austria and Europe. In face of the devastating pandemic events in Italy, just across the Southern border of Tyrol, the Austrian Government decreed a national lockdown as well as ordered an even stricter quarantine for the heavily affected province of Tyrol. Spaces of public life were shut down, tourists fled the resorts and the province as such, and students lost their jobs in tourism and gastronomy. Deprived of their urban social lives and facing a deeply unsettling situation, many young adults, too, left the city to return to their parents' homes or moved in with friends and partners to avoid social isolation. The quarantine for Tyrol was gradually lifted in April and also on a national level, a gradual withdrawal of measures started in mid-April ("100 Tage Corona," 2020).

This health crisis and the resultant societal crisis had been unprecedented for the young adults in particular but also the country as a whole in decades. Thus, the events unfolding in Austria, and particularly in Tyrol, with its provincial capital and single university town of Innsbruck, gave us a unique opportunity to research the agency and strategies of young adults in such a fundamental crisis. While the lives of young people in the Global North such as university students are often thriving on their digital connections in the form of a mobile youth culture (Vanden Abeele, 2016), the pandemic situation proved to be ambivalent for the young adults: It was both a cause for creative innovation in making up for their urban student lives but also an insufficient substitute of these lives, a time of social distancing and of overwhelming connectivity keeping up with online learning and sociability.

Against this background, the article reflects on the following question: How are young adults coping with the disruption of their urban lives and lifestyles and what strategies do they employ to compensate for it? The results shed light on shifted, now dominantly digitally-mediated discourses and imaginaries of the city as well as attempts, successes and pitfalls of digital mediation of urban experiences and activities. Through a qualitative and longitudinal approach that accompanied young adults through the phases of the (first) lockdown and its gradual withdrawal, we seek to reveal the immediate effects of the pandemic on university students' disrupted urban lifestyles and their digital mediation under Covid-19.

\section{The Digitally-Mediated and Imagined City}

In the last two decades geographers, urban planners, media and communication scholars, computer scientists and sociologists have increasingly turned to analysing a variety of foci related to the digital mediation of the city (Bauriedl \& Strüver, 2018; Georgiou, 2011; Leurs \& Georgiou, 2016; Rose, 2017; Willems, 2019). One of these foci is the mediation of everyday urban life and practices through ubiquitous media in the city and urban spaces (see Bork-Hüffer, 2016; Leurs, 2014). This work is particularly engaging with people's everyday mediated practices and experiences of the city. In the context of his work on Chinese cyber-urbanism, Marolt (2014, p. 3) claims that "all online activities by urban Internet users... are at the same time inherently urban and are augmenting traditional understandings of urban space in the sense that the bodies and minds of the people involved are inhabiting and performing urban space." Although we do not agree to the body/mind dichotomy implied in this quote, we do share the idea of the conflation of digital realms to the extent that digital and physical urban spaces can no longer be separated (see Kitchin \& Dodge, 2011; Sumartojo, Pink, Lupton, \& LaBond, 2016). Rather, they must be regarded as "interlinked and entangled socio-material-technological spaces" (Bork-Hüffer, Mahlknecht, \& Kaufmann, 2020, p. 1). Such spaces are not only imprinted by mobilities of data, goods, people and more-than-human materialities but as well by cognitive and imaginary mobilities (Bork-Hüffer, 2016; Cresswell, 2010; Lemos, 2008; Merriman, 2014; Sheller \& Urry, 2006). The latter do not require physical presence but are based on 'connected presence' (Licoppe, 2004) that enables the co-experience of place through digital means from a distance or 'spatial presence' (Croitoru, Wayant, Crooks, Radzikowski, \& Stefanidis, 2015) encompassing the cognitive-psychological relation to place without physically-materially being in those places. Referring to young people's online sociability, Thulin, Vilhelmson, and Schwanen (2020, p. 167) speak of "absent friends," where friendship activities "such as making and updating plans, exchanging and discussing thoughts and experiences, hanging out in groups, confirming feelings, sharing and keeping track of vital events and happenings in each other's lives" are performed online.

Mobile media and mobile communication have further changed everyday practices in urban spaces. Their "anytime, anyplace connectivity" (Vanden Abeele, 
De Wolf, \& Ling, 2018, p. 6) affords individuals a 'microcoordination' (Ling \& Lai, 2016; Ling \& Yttri, 2002) of their social interactions, i.e., the "fine-grained instrumental coordination of everyday life" (Ling \& Lai, 2016, p. 836) on mobile devices while being on the move. The locatability of mobile media devices via GPS also makes it possible for users to engage with places in novel ways in the form of location-based services and spatial media that open up new layers of meaning (Gazzard, 2011; Leszczynski, 2015). For young adults who leave their hometowns, the connectivity of their mobile devices enables them to stay in touch with families and friends despite the physical separation, allowing them "to move geographically from the home and yet remain connected, tethered to a sense of home as an emotional and psychological space of belonging" (Hjorth, 2012, p. 142). On mobile devices, home thus becomes "perpetually experienced-as both lived and imagined-while physically away" (Hjorth, 2012, p. 142). The relief to be able to stay connected to their families back home, at least via smartphones, has been noted to be important to people in crises (see e.g., Kaufmann, 2018).

Yet, the city is not only a stage and reference point for digitally-mediated practices. It is also a contested and desired object of urban imaginaries that goes beyond the physical and corporeal experience. With the increasing proliferation of digital media technologies, social and mobile media "contribute to an understanding of place as not only geographic and physical but also as evoking cartographies of the imaginary, emotional, mnemonic, and psychological" (Hjorth, 2012, p. 140), thus co-producing and amplifying the omnipresent discourses surrounding cities-as well as complicating our relation to the city (see also Leurs \& Georgiou, 2016, p. 3694). Here, the city becomes a "space of imagination" (Leurs \& Georgiou, 2016, p. 3697) that leaves room for "making sense of the self and the proximate and distant world" (Leurs \& Georgiou, 2016, p. 3697). The sudden occurrence of the Covid-19 pandemic indeed provoked novel negotiations of established relations and imaginaries of the city, as we will show below.

\section{Methodology: Collecting Data in a Pandemic}

In face of the acute Covid-19 pandemic, as well as with view to the demands of the specific research ethics of an approach that is sensitive to the situation of individuals in a crisis, we developed and applied a young peoplecentred qualitative longitudinal multi-method approach. Data collection was customised to research under social distancing conditions and thus took place completely online to protect the health of involved participants and researchers. For the research design, we combined written narratives with mobile smartphone methods to stay in contact with participants and interact with them in-situ. This article draws particularly on the results of the narratives. Narratives are an effective qualitative method for exploring individual experiences with and reflections on complex processes of change (Carlsson, Wängqvist, \& Frisén, 2015; Laughland-Booÿ, Skrbiš, \& Newcombe, 2018; McAdams, 2001, 2011). The method gives young participants a voice of their own and room for subjective descriptions and interpretations of their experiences and feelings (see Atkinson, 1998; Pabian \& Erreygers, 2019) as well as more time to reflect on, structure, build and revise their thoughts (see Schulze, 2010). We applied narratives to reveal the breadth of the immediate effects of the pandemic on University students' everyday spaces and practices, as well as their potential variegated and flexible active responses to it. In this way, we wanted to learn in detail how participants make their everyday spaces and practices throughout the pandemic.

Data collection step 1 (DC1, 1-7 April 2020) of the longitudinal study was initiated during the strict lockdown and quarantine measures that were implemented in the federal province of Tyrol to curtail the spread of the new coronavirus. Only shopping for the most basic needs, commuting by essential workers and taking a stroll alone within the borders of each administrative community were allowed at that time. In this phase of data collection, we were especially interested in how the strict lockdown changed our participants' everyday life (contacts, education, sports, work) and everyday practices (both online and offline).

In early April 2020, it was impossible, even for health experts, to foresee for how long the measures taken by the Austrian and Tyrolean governments in response to the pandemic would need to remain in place. Accordingly, we were not able to predict the exact times and end of the data collection steps following DC1 and had to retain flexibility in the implementation of the next DCs. Eventually, DC2 (20-27 April 2020) was realised when the strict quarantine measures in Tyrol were slightly relaxed, and, for example, the reopening of small shops and the crossing of community borders was allowed. DC3 (2-14 June 2020) was conducted in the transition phase directly following the termination of the (first) lockdown to track how the return to life, free from lockdown and self-isolation, is being experienced. We aim to conduct a fourth round of data collection (DC4) during the next lecture period from autumn 2020 onwards, to track to what extent participants' lives have changed to previous daily or new routines (depending on whether the pandemic will change for the better or worse in Autumn). In this article, we draw on results from the narratives of DC1 and DC2, as we are focusing on how life under lockdown conditions was experienced and how study participants coped. The participants were students enrolled at universities in Tyrol aged 18 years or older (thus, legally adults) at the time of DC1. Recruiting took place via snowball sampling, i.e., via the broad networks of our student project team members. This approach enabled us to act swiftly in face of the pandemic and ensured voluntary participation. 98 young adults participated in DC1, 93 in DC2. Both those students who left Innsbruck during the quarantine period 
for their hometowns and less-urban areas and those students who remained in Innsbruck were included in our study. Not only was the development of their relations to Innsbruck investigated, but also to their hometowns, where they stayed during the quarantine period. All participants received a written storytelling prompt for each of the narratives in a Microsoft Word file. In the prompt, they were invited to write a narrative, to file it in a textprocessing software and to return the file directly to us after completion. Participants were asked to report their personal situation, their experiences and thoughts on the continued restrictions (or easing of restrictions) in response to the lead question: "How does the Corona pandemic and the current lockdown change your life?" Also, in every DC step we posed in the narratives questions as further points for reflection, e.g.: "How does the lockdown change your everyday life (contacts, education, sports, work) and your everyday practices? How do your everyday places change (online/offline)? How does your media use change?"

For an analysis of narratives, content analysis is widely employed and recommended as an analysis strategy (see e.g., Vandebosch \& Green, 2019). As we aimed to investigate young adults' disrupted urban lifestyles and their digital mediation under Covid-19, we conducted the 'inductive category development' procedure by Mayring $(2000,2014)$ with the analysis software MaxQDA. For the analysis, we first went through all narratives, gaining an overview of discussed topics. We formulated inductive categories while determining the level of abstraction, and wherever necessary, subsuming and revising existing categories before we completed the qualitative content analysis.

\section{Results: The Flight from the City, Urban Ills and the (Temporary) Digital Mediation of the City}

In this results section, which sheds light on our findings, we first look into what we came to refer to as 'flight' from Innsbruck as experienced by young adults who left the city after lockdown measures were implemented. Second, for these students, from afar, the city was then only experienced through digitally-mediated contents and discourses through which it became constructed as a place of urban ills. Third, bereft of their urban activities and sociability, the participants engaged in digital media appropriation to rearrange their urban lives in the digital sphere for their digitally-mediated urban lives during the pandemic. In terms of their place of stay before the pandemic, in the data, we identified three segments among our participants: (1) A small group of students originally from Innsbruck, who either live with their families or in their rented accommodation in Innsbruck; (2) students who live in the larger region and commute to Innsbruck (including students from bordering communities to some that commute up to three hours by public transport one way, comprising trans-border commutes to neighbouring Northern Italy or Southern Germany regions); and
(3) students from other places in Austria or from abroad who have rented places to stay in Innsbruck. During the pandemic, those based in Innsbruck remained in the city (first segment), whereas those of the second segment remained in their home places outside of Innsbruck. Many students of the third segment left the city early once the pandemic spread through Tyrol and Austria and related lockdown and social distancing measures were implemented by the regional and national governments. Hence, overall, a high number of our study participants spent at least the period of DC1 and DC2 outside the city of Innsbruck, while their experiences and imaginaries of the city became now mediated and constructed from afar.

\subsection{The Flight from the City}

For those participants who temporarily relocated, leaving the city usually meant moving back in with their parent(s) and siblings. For many, it also involved moving from the city of Innsbruck to either smaller urban or rural communities. As higher education institutions in Tyrol are home to a large number of students from abroadparticularly from the bordering states of Southern Tyrol, Italy, and Bavaria and Baden-Württemberg, Germanyfor some, their temporary relocation was transborder. As these states and countries were implementing other local and national measures, this relocation significantly affected the students' exposure to such measures but also their possibilities of return once borders were closed. Travelling home was described by these participants as a solitary and surreal experience. Alexander, who left the city a few weeks into the lockdown and the start of self-isolation measures, described the estrangement to the city when he set out to travel to his family based in another part of Tyrol after his flatmate had also left the city and he eventually no longer endured living alone:

The Anichstraße [main street in front of the university building] was empty, in front of the clinic entrance [there was] a white tent for corona patients and empty streets. The restaurants and shops were closed. On the way to the station, a strange feeling came up in me. The fact that a country can be shut down from 100 to 0 within a few days frightens me a little. There were two people on the bus and the station hall was empty. My journey home took place on 7 April, that is before the mask obligation in the public transport came into force. To be on the safe side I still wore mouth and nose protection. I met only two people on the way from Innsbruck to Kitzbühel. Even when changing trains at the station in Wörgl, [there was] not a soul. (Alexander, 22, DC2)

Besides those study participants who left Innsbruck by temporarily relocating, those who stayed, every once in a while, "fled the city" for activities such as walk- 
ing, hiking, biking, climbing, in the mountains surrounding Innsbruck. According to the Covid-19 regulations in Tyrol, however, only going for a walk within administrative community borders was allowed during the strictest lockdown regulations enforced from around mid-March to mid-April. Several students, such as Sarah, who had moved to Innsbruck from Germany for her studies and in face of the pandemic decided to stay in Innsbruck, reported a new connection to the natural environment surrounding the city, almost a relation they had never felt before:

It finally rained today, yay! I think I have never felt so connected to nature as I do now. There is nothing more beautiful for me than to walk in the forest to the Höttinger painting and breathe in the smell of the forest. Lovely. (Sarah, 25, DC2)

\subsection{Urban IIls as Mediated from Afar}

Those from the second and third segments of participants (students commuting to Innsbruck from the wider region and students with rented places in the city), who either had always been living outside of Innsbruck or who had temporarily relocated, found themselves locationally and socio-materially separated from urban life and space-at least as far as Innsbruck was concerned. Actual happenings in Innsbruck were now followed on (usually online) media or conveyed on social media by those friends and acquaintances that were still based in the city. While not all of these research subjects were concerned with what was going on in Innsbruck, those who did mention the city and urban life in our study often did so in reference to accounts of transgressions of on-going Covid-19 measures such as stay-home orders, social distancing and mask-wearing and risks associated with population densities in cities. Alexander, for example, reported how he was worried by Instagram stories that made him "doubt the sanity of many. Barbecues, birthday parties, family reunions, all this is becoming normal again, although officially the relaxation hasn't even taken effect yet" (Alexander, 22, DC2). Particularly during DC1 and partly during DC2, research subjects were upset by a perceived lack of responsibility of people in urban public places, potentially boosting the spread of the virus and, as a result, prolonging lockdown measures and related economic, social and psychological effects. In these narratives, the city was equated with a place of deviant behaviour and increased dangers in contracting the virus in dense and crowded city spaces and public transport. Strikingly, such accounts were narrated by those not present in the city such as Lukas, who lived in a community neighbouring Innsbruck, just $8 \mathrm{~km}$ from Innsbruck main train station. He recalled:

I heard from a friend of mine who lives in Innsbruck that there are a lot of people on the Inn [river next to the university campus] promenade in the evening, either for jogging/cycling or just to meet each other. For me, it is questionable how useful it is to meet more often now (when it is not necessary), and to do this without a mask. (Lukas, 20, DC2)

However, many participants' worries were not only based on digitally-mediated accounts of the city of Innsbruck, but they referred to the situation in cities more generally. Nele (23, DC1), who had moved back to her family's place in Eastern Tyrol wrote how she was "shocked by images of crowded parks, etc." mediated online. In a similar vein, Emil $(25, \mathrm{DC} 2)$ reported how "this [relaxed behaviour] worries me a lot because as we have seen in Germany, the parks and city centres fill with crowds after the loosening as if the virus had already gone." Here, the city becomes mediated and imagined as a place of deviance and ill on a more general level.

While the city was seen by the young adults as a space whose dwellers do not have much scope to act in a pandemic to keep them and others safe, rural homes and the countryside were associated with low population density and thus less crowded conditions, health security, solitude, closeness to nature and the freedom to move-particularly during DC1 that was conducted during the strict lockdown and stay-at-home orders. Knowing that digital connectivity would ensure them to stay in touch with friends and peers, many young adults preferred in this situation the countryside over the urban centre of Innsbruck.

\subsection{Digitally-Mediated Urban Life}

With their university friends scattered across Tyrol and beyond and all public life put in lockdown, our study participants needed to find ways to make up for their urban social life and urban lifestyles that had suddenly been put on a hold. The urban activities that our participants described as disrupted were diverse, but most centrally the students suffered from a lack of mingling with friends at their homes, at cafés, restaurants, clubs, in the city's open spaces such as the Inn promenade. They missed participating in urban events, such as festivities, or being part of and contributing to non-governmental and community associations based in the city. They missed shopping and wandering through urban space. Further, some dearly struggled with opportunities of keeping up their sportive goals-once they were not able to do sports outside, go to fitness studios and join sports classes-and worried about their educational goals after abruptly being confronted with previously unknown and highly varied ways of distance learning. Yet, as we will show, many were inventive in adapting and shifting parts of these activities and sociability to the digital sphere. However, the degree to which they were satisfied with these mediated activities and experiences of the city and urban life varied greatly.

While our respondents belong to an age group that is usually associated with high media use, under con- 
ditions of lockdown, many participants reported an even increased use of digital devices and digital media both in intensity and breadth of use. For example, Luca described:

All in all, I'm using online media and digital devices much more than before to keep up face-to-face contacts, to educate myself, to distract myself or just to pass the time. Also, the frequency has changed, before the pandemic I was much less on YouTube, etc., but at the moment it is really daily due to study, pastime or entertainment....I have therefore downloaded several apps over the last few weeks, for example, Houseparty, Jitsi and Zoom for video chats. (Luca, 25, DC2)

For many, regular video conferences through Skype, Zoom, WhatsApp, Houseparty, Jitsi in the digital sphere were a way of relating to their now "absent friends" (Thulin et al., 2020, p. 167). These meetings in digital spaces were crucial for a feeling of maintained sociability in general but also for being and staying together and supporting each other through the pandemic as Elisa's account shows:

The social contacts and the spaces in which social contacts take place have changed. For example, my closest friends and I have agreed to have a video conference at least once a week via Skype or WhatsApp. This has worked very well so far and I think it is important, especially in this situation, to take advantage of the opportunity to stay in touch with your friends. (Elisa, 24, DC1)

In DC1, these exchanges were particularly deliberately used by our participants to stay up-to-date and discuss worries, which became already less important at the time of DC2 when infection rates in Tyrol and Austria were in decline and social activities shifted more to having a good time despite the restrictions. In this way, the participants came up with pandemic-compatible solutions for popular joint pastimes such as watching a series together, as Sarah described: "For example, I'm currently watching a series on Netflix with a friend and we're talking on the phone, which is really fun" (Sarah, 25, DC2). Often confined to just a single room in their parents' places, for the young adults, digital media felt all the more "like a gateway to the outside world and friends/acquaintances" (Nele, 23, DC2).

Interestingly, the lockdown and social distancing measures were perceived as freeing the participants also from what now struck them as a "too much" of social meetings and peer pressure that had characterised their lives before Covid-19. These ambivalences in the experiences made by the young adults in the pandemic becomes apparent in Sarah's account who-while highly enjoying novel social activities such as telephoning while watching Netflix (see above)-thrived on the inner peace that suddenly filled her life:
But I hardly miss many things that were once taken for granted. For example: Drinking a lot of alcohol, having house parties or having to do a lot every day. I hope that I can integrate the peace I have gained into my everyday life and that I don't fall back into old patterns too quickly, i.e., that I take the time to read and continue to go out into the fresh air a lot. (Sarah, 25, DC2)

Besides shifting their social activities, many respondents experimented with new applications and platforms to keep themselves occupied, as in the case of Sophia who took up the habit of using the group video chat app Houseparty: "I use the app Houseparty a lot to talk to several people at the same time. I didn't know the app before, but since the beginning of the pandemic, it has been in use almost daily" (Sophia, 22, DC2). The experimentation and appropriation of new apps and tools were not limited to social activities but came up in the narratives also concerning music and sports activities. Bereft of their places of physical exercise, the students searched for digital means that helped them keep in shape and found them in the form of live online sports classes, online sports challenges, fitness videos or workout apps. For example, Nele $(23, \mathrm{DC})$ reflected on her behaviour: "The usage of fitness videos and home workouts has increased many times over (since I usually go to the gym for that)." Likewise, Elena was excited to be able to attend a local yoga course via digital means: "A yoga studio from Innsbruck now offers yoga through Instagram and through Zoom online, which I think is a really nice thing! So, there is the possibility to do sports together with others via video chat" (Elena, 21, DC2). Similarly, Linius $(21, D C 2)$ reported having started learning playing the guitar with the help of an app, while Theo, who in turn taught guitar lessons, appropriated a video editing software to be able to move his music lessons online:

In times of Distance Learning, I also changed my guitar lessons so that I create learning videos and tutorials with my mobile phone or record a song over several tracks and then cut it together as 'play along' with the help of Shotcut [video editing software]. Before the pandemic, I had no experience with this video editing program, but I have learned this program for my own benefit and am now profiting from it myself. (Theo, 28, DC2)

Indeed, Theo was not alone with this more or less forced acquisition of new digital skills. Nina, too, saw the digital platforms they had to use for university once courses were shifted to the digital sphere as an investment for their future career:

I have never dealt with platforms like 'Zoom,' 'Easy Conference,' etc., before. Some of the professors wanted us to create virtual lectureships, but since I have little experience in this area, I had to learn about these platforms first and teach myself how they 
work. But I have to say that I am very happy about this because I think that it can be very useful in my later profession. (Nina, 22, DC2)

Taken together, despite the lockdown measures, all these digital means helped the participants to retain a "halfway normal life, which otherwise would not be imaginable," as Nora (23, DC2) concluded. Luis (22, DC2) agreed in their narrative to this high relevance stating that "online media and digital devices are very important right now. Without them, this crisis would be much more difficult and costly for me to manage."

In contrast to keeping up sociability and maintaining health, work and engagement in associations were hardly suited to be moved online and were instead put on a hold, with some exceptions. For example, while physical demonstrations and charity concerts in public spaces were not possible during the lockdown, Alexander (22, DC2) reported to appreciate and to have engaged with the \#leavenoonebehind initiative which conveyed to him a feeling of solidarity with the wider community and those less fortunate in this global crisis:

Especially the \#leavenoonebehind community is strongly represented on this app. The live concerts try to ease the time until postponed concert dates. Personally, I think it is a good idea that many artists use the time to share their skills online with the world. It's a nice feeling to know that at the same time, people from England, the USA or maybe even your own neighbours are listening to the same concert. The well-known pianist Igor Levit, who usually fills halls like the Hamburg Elbphilharmonie, gives a short online concert almost every day. I'm glad to see that people who normally couldn't afford concert tickets like Mr Levit's can also get access to such artists in such a crisis. It gives a feeling of cohesion and shows that we are all in the same boat. It does not matter whether it is the Prime Minister of Great Britain who falls ill with Covid-19 or an ordinary citizen. No one is immune to the disease. Yet some are better protected, some are barely protected, and others are simply denied protection from the virus. This injustice often makes me think. (Alexander, 22, DC2)

However, particularly in DC2, almost all participants soon commented on the disadvantages of digital sociability and the aspects of urban life they increasingly missed, as mentioned at the beginning of this section. While they were first eager and happy to use digital means of interaction, many of the young adults in our study realised the lacking capabilities of social media to replace face-to-face meetings, the variety of social activities they had previously engaged in and also the physical-material experience of cityscapes. Digital space was appreciated as a way of maintaining friendships throughout the lockdown, yet it did not work for the participants to interact in more meaningful ways. Among the report- ed shortcomings were in particular the lacking quality and depth of digital relationality. Alexander (22, DC2) criticised digitality's lacking ability for bodily and haptic experiences, making him miss "a simple pat on the back or a hug." David (20, DC2) described how he was aware that many people even under strict lockdown had kept on meeting people in physical space. He said that he had some sympathy for them "because otherwise, you'll break down inside. Everyone needs friends or family," meaning thereby one needs them in physical space. Here, it becomes visible that for the young adults used to a socially rich urban life, digital sociability proves to be an insufficient substitute and no more than a temporary solution. Concerning the physical-material experience of the city, Sarah (25, DC2), for example, was eager to "go for a stroll...so just wandering through stores without buying anything."

Already during DC2, when the first relaxation of lockdown measures was enacted in Tyrol, a large part of those respondents who had remained in Innsbruck started meeting friends again in physical space-although most under specified conditions, e.g., encounters restricted to one or very few others to still minimise possibilities for a spread of the virus. While trying to act as reflexive as possible, these respondents invented their own rules of whom to meet, when and how-seeking to conform to regulations while simultaneously breaking them. However, particularly those who had moved to their parents' home or were not living in Innsbruck were now deprived of that possibility and also complained that digital meetings, as a result, were decreasing, cutting them off from their friends even more.

\section{City Life No More? Discussion and Conclusions}

The Covid-19 pandemic has been affecting all parts of daily life for hundreds of millions of people. Students are a group facing tremendous impacts; being in their qualification periods, they are per se in a period of life course change and uncertainty-even without a pandemic around. In this article, we have shed light on how students from the city of Innsbruck coped in very concrete ways with the interruption of their urban lives, lifestyles and activities. Innsbruck was-along with the rest of the province of Tyrol-subject to some of the harshest restrictions related to the Covid-19 pandemic within Austria and north of the Alps. Our findings make visible how despite their often-precarious situation, students were able to manage and showed resilience and resourcefulness in dealing with the situation.

In this article we highlighted three major findings: First, with lockdown measures coming into force, many students left the city, turning it for this group from a socio-materially-technologically experienced place (Bork-Hüffer et al., 2020) to a place solely digitallymediated from afar. The discourses that reached these students through online news media and social media often evoked perceptions and imaginaries of the city as 
a place of ills, constructed as a place where people deviate from expected behaviours under lockdown measures and framed as a risk space for the contraction of the virus. Second, young adults came up with and engaged in various digital activities with the intent to replace and thus keep up urban socio-cultural offline life-reaching from online gatherings, parties, sports classes to music events. As one participant described it, digital media under these conditions proved to be the "gateway to the outside world," being both the only way to experience their university city during the lockdown and an indispensable, yet insufficient lifeline for their sociability. In that sense, during Covid-19, "all online activities by urban Internet users" were not only "inherently urban" as stated, but it was the main (the visible and tangible) urban life that still existed for the young adults (Marolt, 2014 , p. 3, emphasis in original). Hence, (temporarily) previous urban lifestyles, adapted to different degrees to the affordances of digital media, were shifted into digital space (e.g., digital house parties), as well as new innovative ways of digital socialising were created, all in all, producing alternative (digital) forms of an urban lifestyle and truly digitally-mediated urban experiences. Third, during the lockdown period, the importance, use intensity as well as the variety of digital media used by our study participants peaked tremendously. This trend, however, was short-lived as yearned-for offline sociability largely returned to the city once measures were relaxed-while simultaneously, distance learning stayed in place.

Similar to Jacklin-Jarvis and Cole's (2019) evaluation that digital media mainly serve as a way for maintaining friendships and exchange of information, our participants, throughout the lockdown highly appreciated the possibility to socially connect despite the physical distance, but soon pointed to the shortcomings of the digitally-mediated sociability and urban experiences. They dearly missed the city's socio-material spaces of encounter and sociability, making clear that digitallymediated experiences are incapable of making up for urban social life in the long-run. Once those young people who were still based in the city started meeting offline again, their online sociability quickly returned to a state closer to the one before the pandemic. As a result, those who had left the city to join their families in their (often rural) homes or who had previously been commuting to the city from their (parents') homes became even more detached from their urban peers. As a further consequence, students' social relations became reappraised through the course of the pandemic in spring 2020: Those contacts to friends, fellow students and family with whom our participants had either continued to meet offline during lockdown or had quickly returned to meet after the relaxation of the lockdown were significantly strengthened, sometimes perceived as providing an emotional anchor, while other relations to non-family members they could not keep in touch with lost (sometimes strongly) in importance.
Even though our participants perceived digital media and online sociability as insufficient substitutes and were eagerly waiting for restrictions to be relaxed further, the appropriation of new digital apps and services will probably prove useful to them in several regards. First, in case the Covid-19 pandemic worsens in Austria and Europe once more in winter 2020, they will be prepared to adapt and shift their social and urban lives to the digital sphere. They will also know on whom to rely under these circumstances. Second, after the pandemic, when, sooner or later, their everyday lives go back to normal, these young people will probably be able to build on their heightened competence, knowledge and confidence in what digital media can afford them when needed. These affordances were manifold during the pandemic-used for keeping up (urban) sociability, (urban) leisure life, studying and working. In contrast to existing narratives that portray young people as a 'lost' generation that is overwhelmed in dealing with the crisis that the pandemic constitutes (see, e.g., Kahn, 2020; Privitera, 2020), we showed that many of our participants proved to be resilient in several ways in dealing with this situation (see Section 4.3). In this process, digital media played a tremendous role. The experience of self-effectiveness in coping and weathering this situation will most likely have a lasting and formative effect on these young people. Similar to the fundamental and probably permanent changes that currently take place in areas such as work and education, these young adults will build on their current experiences when faced again with disruptions in the future. The sustainability of the effects that this extraordinary situation has on our participants' urban lifestyles and their appreciation of a life closer to nature remains to be seen.

In closing, with this article, we seek to contribute to the very recent and just emerging geographical and interdisciplinary scholarship on the impacts of the ongoing Covid-19 pandemic to "bear witness and make sense of what is happening" (Rose-Redwood et al., 2020, p. 100). We will continue our longitudinal study with another data collection step in autumn 2020. At the time of writing this article in summer 2020, the near future for young people is still more volatile than ever before in their lifetimes. With a renewed (though small) increase in Covid-19 infections in Austria in July 2020, it also seems unlikely for the next study term beginning in October 2020 to return to 'business as usual.' Rather, we can expect months of distance learning ahead, while it remains to be seen how students will continue to handle the on-going restrictions imposed upon their urban lives and sociability by the pandemic.

\section{Acknowledgments}

Christoph Straganz was funded by the doctoral scholarship of the University of Innsbruck at the time of writing this article. We thank the anonymous reviewers as well as Academic Editor Wen Lin for their helpful comments on earlier versions of this manuscript. Above all, 
we are grateful to the participants for their valuable contributions in these challenging times and our student research team members for supporting the conduction of the study.

\section{Conflict of Interests}

The authors declare no conflict of interests.

\section{References}

100 Tage Corona [100 days of Corona]. (2020, June 3). Wiener Zeitung. Retrieved from https://www. wienerzeitung.at/nachrichten/chronik/oesterreich/ 2062831-100-Tage-Corona-Oesterreich-im-Zeichender-Pandemie.html

Atkinson, R. (1998). The life story interview. Thousand Oaks, CA: Sage.

Austrian Agency for International Cooperation in Education and Research. (2017). Study in Austria. Vienna: Austrian Agency for International Cooperation in Education and Research. Retrieved from https://studyinaustria.at/fileadmin/Dokumente/ oead.at/KIM/Downloadcenter/Incoming/WEB_ 20170914_HEI_2017.pdf

Bauriedl, S., \& Strüver, A. (2018). Smart City: Kritische Perspektiven auf die Digitalisierung in Städten: Digitale Technologien, Raumproduktion, Intervention [Smart city: Critical perspectives on digitisation in cities: Digital technologies, production of space, intervention]. Bielefeld: Transcript.

Bork-Hüffer, T. (2016). Mediated sense of place: Effects of mediation and mobility on the place perception of German professionals in Singapore. New Media \& Society, 18(10), 2155-2170. https://doi.org/ $10.1177 / 1461444816655611$

Bork-Hüffer, T., Mahlknecht, B., \& Kaufmann, K. (2020). (Cyber)Bullying in schools: When bullying stretches across cON/FFlating spaces. Children's Geographies. Advance online publication. https://doi.org/ 10.1080/14733285.2020.1784850

Carlsson, J., Wängqvist, M., \& Frisén, A. (2015). Identity development in the late twenties: A never ending story. Developmental Psychology, 51, 334-345.

Cresswell, T. (2010). Towards a politics of mobility. Environment and Planning D: Society and Space, 28(1), 17-31. https://doi.org/10.1068/d11407

Croitoru, A., Wayant, N., Crooks, A., Radzikowski, J., \& Stefanidis, A. (2015). Linking cyber and physical spaces through community detection and clustering in social media feeds. Computers, Environment and Urban Systems, 53, 47-64. https://doi.org/10.1016/ j.compenvurbsys.2014.11.002

Gazzard, A. (2011). Location, location, location: Collecting space and place in mobile media. Convergence: The International Journal of Research into New Media Technologies, 17(4), 405-417. https:// doi.org/10.1177/1354856511414344
Georgiou, M. (2011). Media and the city: Making sense of place. International Journal of Media \& Cultural Politics, 6(3), 343-350. https://doi.org/10.1386/mcp.6.3. 343_3

Hjorth, L. (2012). Still mobile: A case study on mobility, home, and being away in Shanghai. In R. Wilken \& G. Goggin (Eds.), Mobile technology and place (pp. 140-156). London and New York, NY: Routledge.

Hubbard, P. (2006). City. London and New York, NY: Routledge.

Jacklin-Jarvis, C., \& Cole, M. (2019). "It's just houses": The role of community space in a new housing development in the digital era. Voluntary Sector Review, 10(1), 69-79. https://doi.org/10.1332/ 204080519x15478199637975

Kahn, M. (2020, July 9). Coronavirus 'class of 2020': Europe's lost generation? Reuters. Retrieved from https://www.reuters.com/article/us-healthcoronavirus-unemployment-youth/coronavirusclass-of-2020-europes-lost-generationidUSKBN24AOLN

Kaufmann, K. (2018). Navigating a new life: Syrian refugees and their smartphones in Vienna. Information, Communication \& Society, 21(6), 882-898. https://doi.org/10.1080/1369118x.2018.1437205

Kitchin, R., \& Dodge, M. (2011). Code/space: Software and everyday life. London and Cambridge, MA: MIT Press.

Landeshauptstadt Innsbruck. (2020). Innsbruck in Zahlen [Innsbruck in numbers]. Landeshauptstadt Innsbruck. Retrieved from https://www.innsbruck.gv.at/ page.cfm?vpath=wirtschaft--gewerbe/ wirtschaftsstandort-innsbruck/innsbruck-in-zahlen

Laughland-Booÿ, J., Skrbiš, Z., \& Newcombe, P. (2018). Identity and intimacy: A longitudinal qualitative study of young Australians. Journal of Adolescent Research, 33, 725-751. https://doi.org/10.1177/07 43558416684959

Lemos, A. (2008). Mobile communication and new sense of places: A critique of spatialization in cyberculture. Galaxia, 16, 91-109.

Leszczynski, A. (2015). Spatial media/tion. Progress in Human Geography, 39(6), 729-751. https://doi.org/ $10.1177 / 0309132514558443$

Leurs, K. (2014). Digital throwntogetherness: Young Londoners negotiating urban politics of difference and encounter on Facebook. Popular Communication, 12(4), 251-265. https://doi.org/10.1080/15405702. 2014.960569

Leurs, K., \& Georgiou, M. (2016). Digital makings of the cosmopolitan city? Young people's urban imaginaries of London. International Journal of Communication, 10, 3689-3709.

Licoppe, C. (2004). 'Connected' presence: The emergence of a new repertoire for managing social relationships in a changing communication technoscape. Environment and Planning D: Society and Space, 22(1), 135-156. https://doi.org/10.1068/d323t 
Ling, R., \& Lai, C.-H. (2016). Microcoordination 2.0: Social coordination in the age of smartphones and messaging apps. Journal of Communication, 66(5), 834-856. https://doi.org/10.1111/jcom.12251

Ling, R., \& Yttri, B. (2002). Hyper-coordination via mobile phones in Norway. In J. E. Katz \& M. Aakhus (Eds.), Perpetual contact: Mobile communication, private talk, public performance (pp. 139-169). Cambridge: Cambridge University Press.

Marolt, P. (2014). Cyberzomia (Working Paper No. 124). Singapore: Asia Research Institute. Retrieved from https://ari.nus.edu.sg/wp-content/uploads/2018/ 10/wps14_214.pdf

Mayring, P. (2000). Qualitative content analysis. Forum: Qualitative Social Research, 1(2), 1-10. https://doi: 10.17169/fqs-1.2.1089

Mayring, P. (2014). Qualitative content analysis: Theoretical foundation, basic procedures and software solution. SSOAR. Retrieved from https://nbn-resolving. org/urn:nbn:de:0168-ssoar-395173

McAdams, D. P. (2001). The psychology of life stories. General Psychology, 5(2), 100-122. https://doi.org/ 10.1037//1089-2680.5.2.100

McAdams, D. P. (2011). Narrative identity. In S. J. Schwartz, K. Luyckx, \& V. L. Vignoles (Eds.), Handbook of identity theory and research (pp. 99-115). New York, NY: Springer.

Merriman, P. (2014). Rethinking mobile methods. Mobilities, 9(2), 167-187. https://doi.org/10.1080/ 17450101.2013.784540

Pabian, S., \& Erreygers, S. (2019). Generating personal stories on negative online peer interactions through a photo elicitation method. In $\mathrm{H}$. Vandebosch \& $\mathrm{L}$. Green (Eds.), Narratives in research and interventions on cyberbullying among young people (pp. 77-95). Cham: Springer International.

Privitera, G. (2020, July 31). Coronavirus' lost generation. Politico. Retrieved from https://www.politico. eu/article/coronavirus-italy-lost-generation

Rose, G. (2017). Posthuman agency in the digitally mediated city: Exteriorization, individuation, reinvention. Annals of the American Association of Geographers, 107(4), 779-793. https://doi.org/10.1080/ 24694452.2016.1270195
Rose-Redwood, R., Kitchin, R., Apostolopoulou, E., Rickards, L., Blackman, T., Crampton, J., . . Buckley, M. (2020). Geographies of the Covid-19 pandemic. Dialogues in Human Geography, 10(2), 97-106. https://doi.org/10.1177/2043820620936050

Schulze, T. (2010). Zur Interpretation autobiographischer Texte in der erziehungswissenschaftlichen Biographieforschung [On the interpretation of autobiographical texts in educational biography research]. In B. Friebertshäuser, A. Langer, \& A. Prengel (Eds.), Handbuch Qualitative Forschungsmethoden in der Erziehungswissenschaft [Handbook of qualitative research methods in educational science] (pp. 413-436). Weinheim and Munich: Juventa.

Sheller, M., \& Urry, J. (2006). The new mobilities paradigm. Environment and Planning A, 38, 207-226. https://doi.org/10.1068/a37268

Sumartojo, S., Pink, S., Lupton, D., \& LaBond, C. H. (2016). The affective intensities of datafied space. Emotion, Space and Society, 21, 33-40. https://doi.org/ 10.1016/j.emospa.2016.10.004

Thulin, E., Vilhelmson, B., \& Schwanen, T. (2020). Absent friends? Smartphones, mediated presence, and the recoupling of online social contact in everyday life. Annals of the American Association of Geographers, 110(1), 166-183. https://doi.org/10.1080/24694452. 2019.1629868

Vandebosch, H., \& Green, L. (2019). Introduction. In H. Vandebosch \& L. Green (Eds.), Narratives in research and interventions on cyberbullying among young people (pp. 1-8). Cham: Springer International.

Vanden Abeele, M. (2016). Mobile youth culture: A conceptual development. Mobile Media \& Communication, 4(1), 85-101. https://doi.org/10.1177/ 2050157915601455

Vanden Abeele, M., De Wolf, R., \& Ling, R. (2018). Mobile media and social space: How anytime, anyplace connectivity structures everyday life. Media and Communication, 6(2), 5-14. https://doi.org/10.17645/mac. v6i2.13

Willems, W. (2019). 'The politics of things': Digital media, urban space, and the materiality of publics. Media, Culture \& Society, 41(8), 1192-1209. https://doi.org/ $10.1177 / 0163443719831594$

\section{About the Authors}

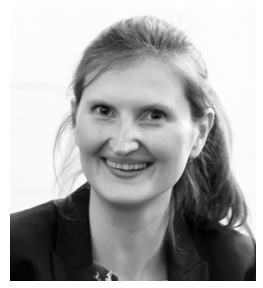

Katja Kaufmann is Postdoctoral Researcher at the Department of Geography, University of Innsbruck, and Guest Researcher at the Institute for Comparative Media and Communication Studies of the Austrian Academy of Sciences and the University of Klagenfurt. She holds a PhD in Communications from the University of Klagenfurt. Her research focuses on mobile media in everyday life, media and migration, and mobile method development. 


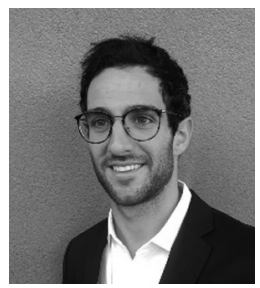

Christoph Straganz is PhD Candidate at the Department of Geography, University of Innsbruck. He completed his Teachers Training diploma in Geography and Sports. His research focuses on pupils and their practices at the institution school as well as in digital space and he applies qualitative and digital methods.

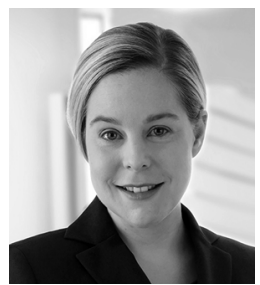

Tabea Bork-Hüffer is Professor for Human Geography at the Department of Geography, University of Innsbruck. Her research centres around the intersections of digitisation, (im-)mobilities, and urbanisation, with a regional focus on Southeast Asia, China, and Austria. Previously she was Alexander-von-Humboldt Foundation Fellow at the Migration Cluster, Asia Research Institute, National University of Singapore and Postdoc at the Department of Geography at the University of Cologne. 